\title{
Effect of thyroid hormone concentration on the transcriptional response underlying induced metamorphosis in the Mexican axolotl (Ambystoma)
}

\author{
Robert B Page ${ }^{\dagger 1,2}$, Stephen R Voss* ${ }^{* 1,2}$, Amy K Samuels ${ }^{1,2}$, \\ Jeramiah J Smith ${ }^{1,2}$, Srikrishna Putta ${ }^{1,2}$ and Christopher K Beachy ${ }^{3,4}$
}

\begin{abstract}
Address: ${ }^{1}$ Department of Biology, University of Kentucky, Lexington Kentucky, 40506 USA, ${ }^{2}$ Spinal Cord and Brain Injury Research Center, University of Kentucky, 40506 USA, ${ }^{3}$ Department of Biology, Minot State University, Minot, North Dakota, 58707 USA and ${ }^{4}$ Amphibian Growth Project, Minot State University, Minot, North Dakota, 58707 USA

Email: Robert B Page - robert.page@uky.edu; Stephen R Voss* - srvoss@uky.edu; Amy K Samuels - salamander@gmail.com;

Jeramiah J Smith - jeramiahsmith@gmail.com; Srikrishna Putta - sputt2@uky.edu; Christopher K Beachy - christopher.beachy@minotstateu.edu

* Corresponding author †Equal contributors
\end{abstract}

Published: II February 2008

BMC Genomics 2008, 9:78 doi:10.1 186/147|-2164-9-78

This article is available from: http://www.biomedcentral.com/I47I-2/64/9/78

(C) 2008 Page et al; licensee BioMed Central Ltd.

This is an Open Access article distributed under the terms of the Creative Commons Attribution License (http://creativecommons.org/licenses/by/2.0), which permits unrestricted use, distribution, and reproduction in any medium, provided the original work is properly cited.
Received: 2 November 2007

Accepted: II February 2008

\begin{abstract}
Background: Thyroid hormones (TH) induce gene expression programs that orchestrate amphibian metamorphosis. In contrast to anurans, many salamanders do not undergo metamorphosis in nature. However, they can be induced to undergo metamorphosis via exposure to thyroxine $\left(\mathrm{T}_{4}\right)$. We induced metamorphosis in juvenile Mexican axolotls (Ambystoma mexicanum) using 5 and $50 \mathrm{nM} \mathrm{T}_{4}$, collected epidermal tissue from the head at four time points (Days 0, 2, 12, 28 ), and used microarray analysis to quantify mRNA abundances.

Results: Individuals reared in the higher $\mathrm{T}_{4}$ concentration initiated morphological and transcriptional changes earlier and completed metamorphosis by Day 28. In contrast, initiation of metamorphosis was delayed in the lower $\mathrm{T}_{4}$ concentration and none of the individuals completed metamorphosis by Day 28 . We identified 402 genes that were statistically differentially expressed by $\geq$ two-fold between $T_{4}$ treatments at one or more non-Day 0 sampling times. To complement this analysis, we used linear and quadratic regression to identify 542 and 709 genes that were differentially expressed by $\geq$ two-fold in the 5 and $50 \mathrm{nM} \mathrm{T}_{4}$ treatments, respectively.

Conclusion: We found that $T_{4}$ concentration affected the timing of gene expression and the shape of temporal gene expression profiles. However, essentially all of the identified genes were similarly affected by 5 and $50 \mathrm{nM} \mathrm{T}_{4}$. We discuss genes and biological processes that appear to be common to salamander and anuran metamorphosis, and also highlight clear transcriptional differences. Our results show that gene expression in axolotls is diverse and precise, and that axolotls provide new insights about amphibian metamorphosis.
\end{abstract}

\section{Background}

Amphibian metamorphosis is generally characterized by dramatic and conspicuous developmental changes that are necessary for larvae to function as terrestrial adults. The morphological, behavioral, and physiological changes that occur during metamorphosis are associated 
with increases in thyroid hormone (triiodothyronine, $\mathrm{T}_{3}$ and thyroxine, $\left.\mathrm{T}_{4} ; \mathrm{TH}\right)[1,2]$ and RNA synthesis [3]. These events are interconnected; at metamorphosis, tissue-specific concentrations of TH activate and repress transcriptional networks within target cells that in turn regulate new patterns of development [4]. Many genes that are associated with molecular and morphological events during metamorphosis have been identified from studies of anurans, and in particular Xenopus laevis. In contrast, little is known about patterns of gene expression during salamander metamorphosis.

Although anuran and salamander metamorphosis are regulated by many of the same endocrine factors, there is considerable developmental variation between these groups. Most conspicuously, some salamanders do not undergo a complete metamorphosis in nature. These salamanders are called paedomorphs because they retain larval characteristics into the adult stage, and because genetic and phylogenetic evidence suggests that they evolve from metamorphic ancestors $[5,6]$. Paedomorphosis in the Mexican axolotl (Ambystoma mexicanum) is associated with low hypothalamic-pituitary-thyroid (HPT) activity and differential sensitivity of tissues to TH that results in some cryptic biochemical and molecular changes, but not the complete suite of morphological changes seen in related, metamorphic tiger salamanders. Interestingly, $A$. mexicanum can be induced to undergo anatomical metamorphosis by administering $\mathrm{TH}$ and endocrine factors that function upstream of TH synthesis $[7,8]$. The axolotl provides an excellent alternative to anuran systems because metamorphosis can be precisely induced and studied in juveniles or adults that are not developing toward a metamorphic outcome.

Functional genomic approaches are beginning to reshape the way transcription is conceptualized during amphibian metamorphosis [9-11]. The transcriptional program for tissue regression, remodeling, and organogenesis is significantly more complicated than was initially predicted for Xenopus [12-15]. Previously, we used microarray technology to identify keratin biomarkers for $\mathrm{T}_{4}$ induced metamorphosis in the integument (epidermis) of the Mexican axolotl [11]. We showed that $50 \mathrm{nM} \mathrm{T}_{4}$ induces a complex transcriptional program and axolotls complete metamorphosis with no mortality. Interestingly, this $\mathrm{T}_{4}$ concentration is known to affect gene expression and mortality in anurans [16-18] and it is higher than $\mathrm{T}_{4}$ concentrations estimated in the serum of spontaneously metamorphosing salamanders. For example, Larras-Regard et al. [2] reported $28 \mathrm{nM}$ as the maximum serum $\mathrm{T}_{4}$ level in Ambystoma tigrinum, a close relative of the axolotl that typically undergoes metamorphosis. To further investigate the effect of $\mathrm{T}_{4}$ concentration on induced metamorphosis in the Mexican axolotl, we report the results of a second microarray experiment that induced metamorphosis using a much lower concentration of $\mathrm{T}_{4}(5 \mathrm{nM})$. Using 5 and $50 \mathrm{nM} \mathrm{T}_{4}$ microarray datasets, we describe the temporal transcriptional response of $\mathrm{T}_{4}$ induced metamorphosis and specifically address the following question: Does $\mathrm{T}_{4}$ concentration affect morphological metamorphosis and gene expression in the axolotl? We discuss the biological significance of some of the differentially expressed genes (DEGs) that were identified and the relationship between salamander and anuran metamorphic gene expression programs.

\section{Results \\ Effect of $\mathrm{T}_{4}$ concentration on morphological metamorphosis}

During $\mathrm{T}_{4}$ induced metamorphosis, Mexican axolotls progress through developmental stages (0-IV) [19] that are defined by the resorption of the upper and lower tailfins, dorsal ridge, and gills. We staged all axolotls after 0 , 2,12 , and 28 days of $\mathrm{T}_{4}$ treatment. No metamorphic changes were observed after two days of $\mathrm{T}_{4}$ treatment and thus axolotls from both $\mathrm{T}_{4}$ treatments were assigned to Stage 0. At Day 12, morphological changes were observed in $50 \mathrm{nM} \mathrm{T}_{4}$ treated axolotls (Stages I and II) but $5 \mathrm{nM} \mathrm{T}_{4}$ treated axolotls were indistinguishable from control animals (Stage 0). At Day 28, axolotls reared in $50 \mathrm{nM} \mathrm{T}_{4}$ had fully resorbed tailfins and gills, and thus had completed morphological metamorphosis (Stage IV). Between Days 12 and 28, $5 \mathrm{nM} \mathrm{T}_{4}$ treated axolotls initiated metamorphosis but did not complete all morphological changes by Day 28 (Stage III). On average, individuals complete metamorphosis after 35 days in $5 \mathrm{nM} \mathrm{T}_{4}$ (unpublished data). Thus, a low concentration of $\mathrm{T}_{4}$ delays the initiation timing of morphological metamorphosis but not the length of the metamorphic period.

\section{Gene expression in the absence of $T_{4}$}

Our first set of statistical analyses tested control axolotls for temporal changes in mRNA abundance that were independent of $\mathrm{T}_{4}$ treatment [see Additional files 1, 2]. Temporal changes are expected if patterns of transcription (gene expression) change significantly over time as salamanders mature, or if there are uncontrolled sources of experimental variation. After adjusting the false discovery rate (FDR) to 0.05 , none of the probe-sets (genes) on the custom Ambystoma GeneChip were identified as significantly differentially abundant as a function of time. Thus, we found no statistical support for differential gene expression among control animals.

\section{Gene expression in the presence of $T_{4}: 5$ versus $50 \mathrm{nM}$}

At each of the times that we estimated mRNA abundances during $\mathrm{T}_{4}$ induced metamorphosis, the number and diversity of genes that were differentially expressed between the 5 and $50 \mathrm{nM} \mathrm{T}_{4}$ treatments differed (Figure 1A) [see Addi- 


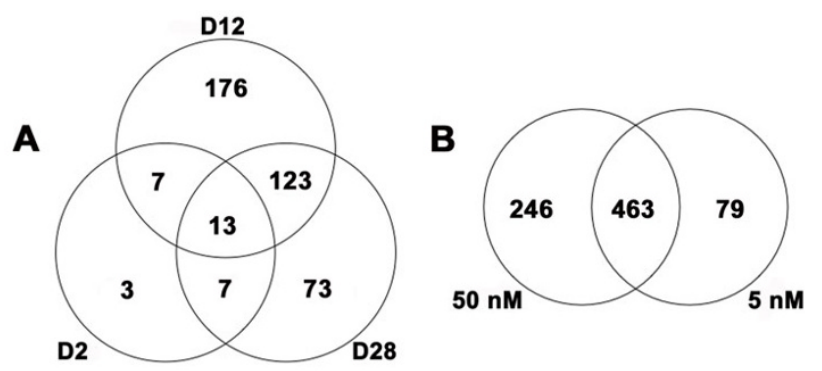

Figure I

Results of the statistical analyses conducted on the microarray data. (A) Venn diagram showing the DEGs identified at specific time points by contrasting the two $T_{4}$ concentrations and imposing fold change criteria. D2 = Day 2, DI2 = Day 12, and D28 = Day 28. (B) Venn diagram depicting the relationship between DEGs that were identified via the 5 and $50 \mathrm{nM}$ regression analyses and imposing fold change criteria. For panel $\mathrm{B}$, fold change values are relative to Day 0. tional files 3,4]. A total of 402 DEGs that differed by $\geq$ two-fold at one or more of our sampling times were identified among all day by $\mathrm{T}_{4}$ treatment contrasts (Figure $1 \mathrm{~A}$ ) [see Additional files 3, 4]. We identified 30 DEGs as early as Day 2 (Table 1), and eighty percent of these DEGs were up regulated in $50 \mathrm{nM} \mathrm{T}_{4}$ relative to $5 \mathrm{nM} \mathrm{T}_{4}$. This small group of early response genes was statistically associated with the amino acid transport and amine transport ontology terms. Additional gene functions of these early responding genes include epithelial differentiation, ion transport, RNA processing, signal transduction, and apoptosis/growth arrest. We note that no differentially expressed transcription factors were identified as DEGs at Day 2, and neither thyroid hormone receptor (TR; alpha and beta) was identified as differentially expressed at any time point in our study. At Day 12, when axolotls in 50 $\mathrm{nM} \mathrm{T}$ were undergoing dramatic tissue resorption events and axolotls in $5 \mathrm{nM} \mathrm{T}_{4}$ were indistinguishable from controls, we identified the greatest number of DEGs between the $\mathrm{T}_{4}$ treatments $(n=319$; Figure $1 \mathrm{~A})$. An approximately equivalent number of up and down regulated DEGs were identified [see Additional files 3, 4]. These genes were

Table I: Genes identified as differentially abundant between 5 and $50 \mathrm{nM} \mathrm{T}_{4}$ at Day 2

\begin{tabular}{|c|c|c|c|c|c|}
\hline Gene & Probe-set ID & Contig ID & $t$ & $P$ & Fold Change \\
\hline Actin, alpha, cardiac muscle & SRV_I2180_x_at & TC01592 & -4.17 & 0.0004 & -8.91 \\
\hline N/A & SRV_07408_at & MC0729I & -2.49 & 0.0209 & -2.83 \\
\hline Solute carrier family 7 , member 3 & SRV_04996_at & MC04879 & -2.33 & 0.0295 & -2.47 \\
\hline Lipopolysaccharide-induced TNF factor & SRV_0592I_at & MC05804 & -2.66 & 0.0144 & -2.38 \\
\hline $\mathrm{N} / \mathrm{A}$ & SRV_09913_at & MC09796 & -2.98 & 0.0069 & -2.22 \\
\hline Regulator of G-protein signaling 5 & SRV_01913_a_at & MCoI80I & -2.35 & 0.0283 & -2.18 \\
\hline Cadherin I, type I, E-cadherin & SRV_II96I_at & TC0I382 & 4.19 & 0.0004 & 5.65 \\
\hline ATP-binding cassette, sub-family B, member 4 & SRV_10722_at & TC00206 & 3.11 & 0.0051 & 5.64 \\
\hline N/A & SRV_05709_at & MC05592 & 3.84 & 0.0009 & 4.79 \\
\hline N/A & SRV_057I0_a_at & MC05593 & 4.93 & $<0.0001$ & 4.78 \\
\hline N/A & SRV_10033_at & MC09916 & 3.90 & 0.0008 & 3.25 \\
\hline Solute carrier family 6, member 14 & SRV_03196_a_at & MC03084 & 2.79 & 0.0108 & 3.00 \\
\hline N/A & SRV_10338_at & MCI022I & 2.69 & 0.0134 & 2.63 \\
\hline N/A & SRV_07637_at & MC07520 & 2.80 & 0.0104 & 2.44 \\
\hline Transglutaminase I & SRV_00309_at & MC00I97 & 2.69 & 0.0134 & 2.28 \\
\hline Phosphoenolpyruvate carboxykinase I & SRV_0I492_at & MCOI380 & 2.57 & 0.0177 & 2.24 \\
\hline $\mathrm{N} / \mathrm{A}$ & SRV_08888_at & MC0877I & 2.28 & 0.0324 & 2.04 \\
\hline N/A & SRV_0773I_at & MC076I4 & 2.39 & 0.0258 & 2.04 \\
\hline Adipose differentiation-related protein & SRV_00744_a_at & MC00632 & 2.06 & 0.0501 & 1.89 \\
\hline Chemokine ligand 5 & SRV_0I687_at & MC0I575 & 2.81 & 0.0102 & 1.72 \\
\hline N/A & SRV_078I6_a_at & MC07699 & 2.32 & 0.0304 & 1.68 \\
\hline N/A & SRV_05752_at & MC05635 & 3.11 & 0.0051 & 1.64 \\
\hline Heterogeneous nuclear ribonucleoprotein L-like & SRV_05212_a_at & MC05095 & 2.59 & 0.0168 & 1.57 \\
\hline Transmembrane protein 79 & SRV_04923_at & MC04806 & 2.19 & 0.0396 & 1.53 \\
\hline N/A & SRV_07996_at & MC07879 & 2.81 & 0.0102 & I.5 I \\
\hline N/A & SRV_06589_at & MC06472 & 2.05 & 0.0525 & $\mathrm{I} .44$ \\
\hline N/A & SRV_05658_a_at & MC0554I & 2.17 & 0.0410 & 1.43 \\
\hline Solute carrier family II, member I & SRV_0044I_at & MC00329 & 2.32 & 0.0301 & $\mathrm{I} .34$ \\
\hline Dystroglycan I & SRV_02177_at & MC02065 & 2.44 & 0.0232 & 1.30 \\
\hline Mitogen-activated protein kinase kinase 3 & SRV_05297_at & MC05I80 & 2.32 & 0.0303 & 1.20 \\
\hline
\end{tabular}

N/A refers to genes that do not have established orthologies to human. Probe-set ID represents the unique identifier for each probe-set on the custom Ambystoma GeneChip. Contig ID represents the Sal-Site [52] identifier for contigs associated with each probe-set. All fold changes are relative to the 5 $\mathrm{nM}$ dataset. Thus positive values are up regulated in $50 \mathrm{nM}$ samples relative to $5 \mathrm{nM}$ samples and negative values are down regulated in $50 \mathrm{nM}$ samples relative to $5 \mathrm{nM}$ samples. 
enriched for functions associated with epidermis development, carbohydrate metabolism, ectoderm development, response to chemical stimulus, negative regulation of cell proliferation, response to abiotic stimulus, negative regulation of biological process, development, and organ development. By Day 28, when axolotls in $50 \mathrm{nM} \mathrm{T}_{4}$ had completed metamorphosis and axolotls in $5 \mathrm{nM} \mathrm{T}_{4}$ were continuing to show morphological restructuring, we identified 216 DEGs that differed between the $\mathrm{T}_{4}$ treatments (Figure 1A). Of the identified DEGs, $76 \%$ were down regulated in $50 \mathrm{nM} \mathrm{T}_{4}$ relative to $5 \mathrm{nM} \mathrm{T}_{4}$ [see Additional files $3,4]$. DEGs identified at Day 28 were associated with response to pest, pathogen, or parasite, negative regulation of cellular process, positive regulation of physiological process, response to stress, response to stimulus, transition metal ion transport, di-, tri-valent inorganic cation transport, response to other organism, immune response, development, organismal physiological process, muscle contraction, response to biotic stimulus, and response to bacteria. The functional categories that we identified show that the axolotl epidermal transcriptional response to $\mathrm{T}_{4}$ is complex, involving hundreds of DEGs.

To further explore the effect of T4 on gene expression and morphological metamorphosis we conducted a principal component analysis (PCA). This analysis shows that global gene expression and morphological metamorphosis are strongly correlated, but there is little or no correlation between gene expression and T4 treatment (Figure 2). This suggests that after metamorphosis was initiated within T4 treatments, molecular and morphological events were coordinately regulated. T4 concentration affected the onset timing of metamorphosis in axolotls, but not the sequence of transcriptional and morphological events that define this process.

\section{Modeling the transcriptional response of genes during induced metamorphosis}

To further investigate the effect of $\mathrm{T}_{4}$ concentration on induced metamorphosis, we modeled mRNA abundance estimates from the 5 and $50 \mathrm{nM} \mathrm{T}_{4}$ treatments using quadratic and linear regression. The regression analyses identified 542 and 709 DEGs that changed by $\geq$ two-fold relative to Day 0 controls, in the 5 and $50 \mathrm{nM} \mathrm{T}_{4}$ treatments respectively [see Additional files 5, 6, 7, 8]. Given our previous analyses, we expected to observe different regression patterns (expression profiles; Figure 3) for DEGs from each treatment because metamorphic initiation timing was delayed in $5 \mathrm{nM} \mathrm{T}_{4}$ and metamorphosis was only completed in $50 \mathrm{nM} \mathrm{T}_{4}$. Indeed, most DEGs identified by the $5 \mathrm{nM}$ regression analysis exhibited linear expression profiles during metamorphosis (e.g., linear down, LD; linear up, LU; Figure 3) while the majority of the DEGs identified by the $50 \mathrm{nM}$ regression analysis exhibited curvilinear and parabolic expression profiles

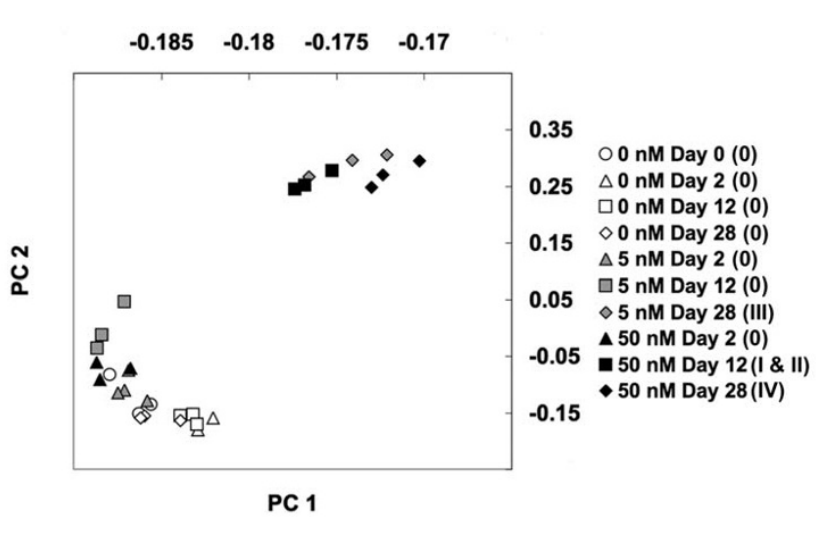

Figure 2

Results of the principal component analysis. Scatter plots of the 30 GeneChips based on the rotations of their first two principal components (PC I and PC 2). PCA was performed on all 3688 probe-sets that were available for significance testing. PC I and PC 2 account for $89.2 \%$ and $6.2 \%$ of the variance respectively. Cano-Martinez stages are listed in parenthesis in the legend.

(e.g., quadratic linear convex down, QLVD; quadratic linear concave up QLCU; quadratic convex QV; quadratic concave, QC; Figure 3; see the methods for a summary of the biological interpretations of these expression profiles in the context of our experiment). Thus, biological processes known to be fundamental to tissue remodeling and/ or development were identified from both $\mathrm{T}_{4}$ treatments, however they were statistically associated with different regression patterns (Figure 3). For example, four collagendegrading matrix metallopeptidase (MMP) genes (MMP13, MMP9, MMP1) exhibited linear up regulated responses in $5 \mathrm{nM} \mathrm{T}_{4}$ and were categorized as LU. However, under $50 \mathrm{nM} \mathrm{T}_{4}$, these genes were categorized among the QC and QLCU profiles. Several genes associated with organ development (transgelin, mitogen-activated protein kinase 12, distal-less homeo box 3, actin binding lim protein 1, collagen type VI alpha 3, and msh homeo box homolog 2) were up regulated in a linear fashion in $50 \mathrm{nM} \mathrm{T}_{4}$ and were categorized as LU. In $5 \mathrm{nM} \mathrm{T}_{4}$, several of these genes (mitogenactivated protein kinase 12, actin binding lim protein 1, and msh homeo box homolog 2) were statistically significantly up regulated (LU and QLVU) but failed to eclipse our twofold change criteria. A single gene (collagen type VI alpha 3) was not statistically significant and categorized as "Flat" in $5 \mathrm{nM} \mathrm{T}_{4}$. However, this gene did not appreciably deviate from base-line expression levels until Day 28 in $50 \mathrm{nM} \mathrm{T}_{4}$ (Figure 4A). We attribute these differences between the $\mathrm{T}_{4}$ treatments to the delayed onset timing of metamorphosis in the $5 \mathrm{nM} \mathrm{T}_{4}$ treatment. Overall, the same generalized direction of expression was observed for 457 of 463 (99\%) DEGs that were commonly identified from both $\mathrm{T}_{4}$ treatments (Figure 1B). The six genes (calponin 2, ethyl- 


\section{Down-regulated Regression Patterns}

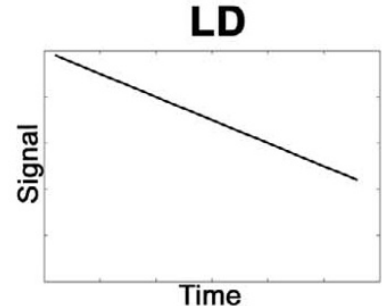

5 nM (205): Neurophysiological process, Immune response, Sensory perception, Response to virus, Response to stimulus, Defense response $50 \mathrm{nM}$ (125): Response to pest pathogen or parasite, Antigen processing endogenous antigen via MHC class I, Response to stimulus, Immune response, Antigen presentation, Defense response

LU

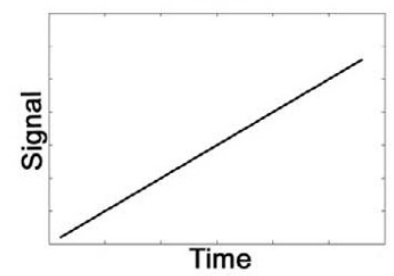

5 nM (184): Collagen catabolism, Epidermis development, Biopolymer catabolism, Tissue development, Organic acid metabolism, Amino acid metabolism, Ion transport, $50 \mathrm{nM}$ (86): Organ development, Phosphate transport, Ion transport

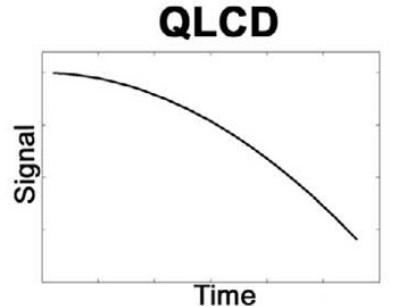

$5 \mathrm{nM}$ (66): Localization within membrane

$50 \mathrm{nM}$ (41): Response to pest pathogen or parasite, Response to stress, Response to stimulus, Iron ion transport, Response to other organism, Immune response, lon transport, Defense response, Response to bacteria

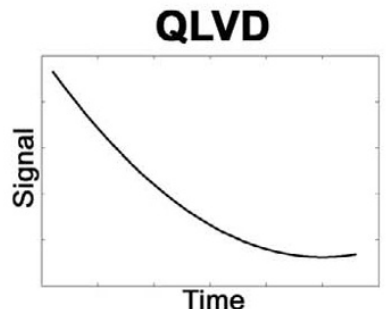

5 nM (4): No significant GO terms

$50 \mathrm{nM}$ (188): Response to biotic stimulus

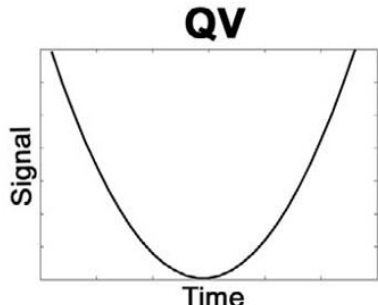

$5 \mathrm{nM}$ (0): No significant GO terms

$50 \mathrm{nM}$ (30): Negative regulation of cellular process, Negative regulation of transcription DNA dependent, Regulation of transcription from RNA polymerase II promoter, Negative regulation of nucleic acid metabolism, Negative regulation of metabolism

\section{Up-regulated Regression Patterns}

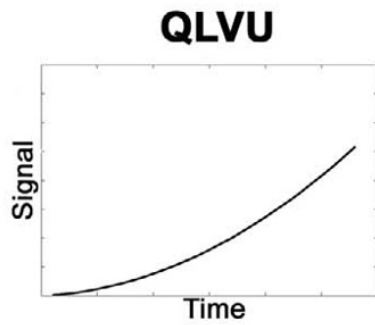

$5 \mathrm{nM}$ (66): No significant GO terms $50 \mathrm{nM}$ (5): No significant GO terms

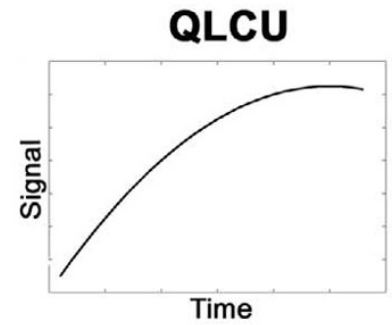

$5 \mathrm{nM}$ (17): No significant Go terms

$50 \mathrm{nM}$ (181): Protein

polymerization, Carboxylic acid metabolism, Ectoderm development, Organic acid metabolism, Tissue development, Amino acid and derivative metabolism, Epidermis development, Transport

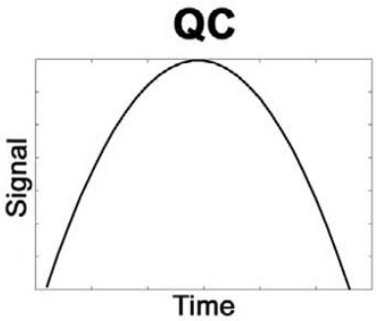

$5 \mathrm{nM}(0)$ : No significant GO terms $50 \mathrm{nM}$ (53): Macromolecule metabolism, Biopolymer catabolism, Protein catabolism, Cellular carbohydrate metabolism, Protein metabolism

Figure 3

Generalized regression patterns. The generalized regression patterns recovered by the methodology described in Liu et al. [52]. The units and values of the axes are arbitrary. The number of probe-sets in each category is listed in parentheses by concentration. Significantly enriched biological process gene ontology terms are listed by concentration and pattern. In some cases specific terms were too abundant and were thus summarized via a broader term. Abbreviations are as follows $L D=$ linear down, $\mathrm{QLCD}=$ quadratic linear concave down, $\mathrm{QLVD}=$ quadratic linear convex down, $\mathrm{LU}=$ linear up, $\mathrm{QLCU}=$ quadratic linear concave up, $\mathrm{QLVU}=$ quadratic linear convex up, $\mathrm{QC}=$ quadratic concave, and $\mathrm{QV}=$ quadratic convex. $\mathrm{A}$ ninth pattern (Flat) that describes null results is not shown.

malonic encephalopathy 1, 3' repair exonuclease 2, SRV_05658_a_at, SRV_09880_at, and N-myc downstream regulated gene 1) that seemingly exhibited opposite directions of expression in 5 and $50 \mathrm{nM} \mathrm{T}_{4}$ were all categorized the same way (LU in $5 \mathrm{nM} \mathrm{T}_{4}$ and QLCD in $50 \mathrm{nM} \mathrm{T}_{4}$ ). Closer inspection of these expression profiles revealed that genes classified as QLCD trend upward at the early time points before decreasing at later time points (Figure 


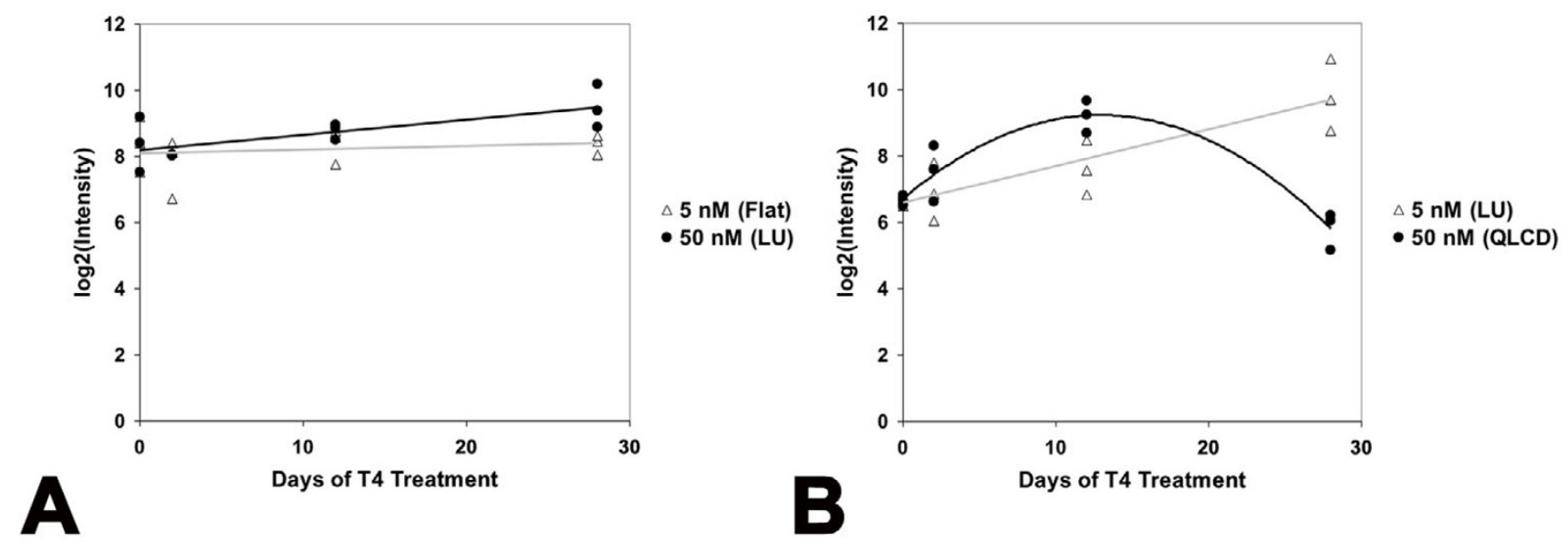

Figure 4

Example regression profiles. Example regression profiles based on microarray data from a gene that does not appreciably deviate from baseline until Day 28 in $50 \mathrm{nM} \mathrm{T}_{4}$ (A; collagen, type VI, alpha 3; probe-set ID: SRV_05I03_a_at) and a gene that is initially up regulated in $50 \mathrm{nM} \mathrm{T}_{4}$ before being down regulated (B; N-Myc downstream regulated gene I; probe-set ID:

SRV_124I7_at). Trend lines for the $5 \mathrm{nM}$ regression analyses are gray and trend lines for the $50 \mathrm{nM}$ regression analyses are black. $L U=$ linear up and $\mathrm{QLCD}=$ quadratic linear concave down.

$4 \mathrm{~B})$. These results show that $\mathrm{T}_{4}$ concentration affected the shape of temporal gene expression profiles but essentially all epidermal DEGs that were identified in both $\mathrm{T}_{4}$ treatments were regulated in the same direction by 5 and 50 $\mathrm{nM} \mathrm{T}_{4}$.

The regression analyses identified a number of DEGs that only met both of our criteria (statistically significant and $\geq$ two-fold change) in one of the T4 concentrations ( $5 \mathrm{nM}$, $\mathrm{n}=79 ; 50 \mathrm{nM}, \mathrm{n}=246$; Figure $1 \mathrm{~B})$. Of the 79 genes unique to $5 \mathrm{nM} \mathrm{T} 4,36(46 \%)$ were statistically significant in 50 $\mathrm{nM}$ T4 but did not eclipse our two-fold change criteria. Of the remaining 43 genes unique to $5 \mathrm{nM} \mathrm{T4}, 25$ exhibited $\geq$ two-fold change in $50 \mathrm{nM}$ T4 at one or more sampling times but were not statistically significant. Inspection of the $50 \mathrm{nM}$ T4 regression patterns and fold change data associated with the 79 genes unique to $5 \mathrm{nM}$ T4 revealed that all of these genes exhibited similar directional trends (up versus down regulation) in 5 and $50 \mathrm{nM}$ T4 [see Additional files 9, 10]. Of the 246 genes unique to $50 \mathrm{nM} \mathrm{T} 4$, 96 (39\%) were statistically significant in $5 \mathrm{nM} \mathrm{T4}$, but failed to eclipse our two-fold change criteria. An additional 48 genes exhibited $\geq$ two-fold change for at least one sampling time in $5 \mathrm{nM}$ T4, but were not statistically significant. Inspection of the $5 \mathrm{nM}$ T4 regression patterns and fold change data associated with the 246 genes unique to $50 \mathrm{nM} \mathrm{T4}$ demonstrated that 209 (85\%) of these genes exhibited similar directional trends in 5 and $50 \mathrm{nM}$ T4 [see Additional files 11, 12]. An additional 22 genes unique to $50 \mathrm{nM}$ T4 did not exhibit $>1.5$ fold changes relative to Day 0 controls until Day 28 (at which time they were differentially regulated by $\geq$ two-fold), suggesting that they are expressed during the terminal stages of metamorphosis [see Additional files 11, 12]. Presumably, these genes were not detected in $5 \mathrm{nM}$ T4 because we did not sample latter time points for this concentration. These results reiterate the point that essentially all genes identified by our study were similarly, directionally expressed in the 5 and $50 \mathrm{nM}$ T4 treatments.

To address similarity in terms of magnitude, we compared maximum fold level values for genes that exhibited QLVD and QLCU expression profiles in both T4 treatments (Figure 3; Table 2). We assumed that genes exhibiting these profiles had achieved maximum/minimum mRNA levels during the experiment, and thus could be reliably compared between treatments. No statistical differences were observed for fold level values of 13 QLVD and QLCU genes between the 5 and $50 \mathrm{nM} \mathrm{T} 4$ treatments (Wilcoxon signed rank test, $Z=-1.293, P=0.1961)$ [20], and the fold level values were highly correlated (Table 2; Spearman's rho $=1.00, \mathrm{P}<0.0001)$ [20]. Although this analysis was performed on a small subset of genes, the results suggest that mRNA abundances are similar for genes that are differentially expressed in 5 and $50 \mathrm{nM} \mathrm{T4}$.

\section{Bioinformatic comparison: axolotl versus Xenopus}

Salamanders and anurans may express similar genes during amphibian metamorphosis. To test this idea, we compared a list of 'core' up regulated metamorphic genes from 
Table 2: Genes categorized as QLVD and QLCU in both $T_{4}$ treatments

\begin{tabular}{|c|c|c|c|c|}
\hline Gene & Probe-set ID & Fold Change $5 \mathrm{nM}$ & Fold Change $50 \mathrm{nM}$ & Profile \\
\hline Serpin peptidase inhibitor clade $B$ member 10 & SRV_024I8_at & 3.60 & 3.24 & QLCU \\
\hline Serpin peptidase inhibitor clade B member 2 & SRV_04787_s_at & 4.23 & 3.76 & QLCU \\
\hline N/A & SRV_05867_a_at & 21.70 & 21.44 & QLCU \\
\hline N/A & SRV_05889_x_at & 11.05 & 11.01 & QLCU \\
\hline$N / A$ & SRV_06225_at & 24.98 & 26.20 & QLCU \\
\hline N/A & SRV_07624_x_at & 9.64 & 9.60 & QLCU \\
\hline N/A & SRV_10263_at & 72.28 & 70.70 & QLCU \\
\hline N/A & SRV_10508_a_at & 86.94 & 86.10 & QLCU \\
\hline Keratin $6 E$ & SRV_I4426_at & 2.97 & 2.95 & QLCU \\
\hline WAP four-disulfide core domain 5 & SRV_05575_at & 24.23 & 23.40 & QLCU \\
\hline Keratin 4 & SRV_12057_at & 327.01 & 417.46 & QLCU \\
\hline Desmin & SRV_0I373_at & -51.18 & -50.21 & QLVD \\
\hline$N / A$ & SRV_01375_at & -6.03 & -5.90 & QLVD \\
\hline
\end{tabular}

N/A refers to genes that do not have established orthologies to human. Probe-set ID represents the unique identifier for each probe-set on the custom Ambystoma GeneChip. Fold change $5 \mathrm{nM}$ refers to the maximum fold change observed in the $5 \mathrm{nM} \mathrm{T}_{4}$ treatment relative to Day 0 controls. Fold change $50 \mathrm{nM}$ refers to the maximum fold change observed in the $50 \mathrm{nM} \mathrm{T}_{4}$ treatment relative to Day 0 controls. Profile refers to the expression profile for each gene obtained from regression analyses on the 5 and $50 \mathrm{nM} \mathrm{T}_{4}$ datasets. QLCU refers to the quadratic linear concave up regression profile and QLVD refers to the quadratic linear convex down regression profile.

Xenopus [10] to DEGs identified from our study of axolotl. Of the 59 genes that were reported as differentially up regulated by $\geq 1.5$ fold in limb, brain, tail, and intestine from metamorphosing Xenopus, 23 (39\%) are represented by at least one of the 3688 probe-sets analyzed in our study. Of these, only two (FK506 binding protein 2 and glutamatecysteine ligase modifier subunit) were identified as statistically significant and differentially expressed by $\geq$ two-fold in our study [see Additional files 13, 14]. FK506 binding protein 2 was up regulated in axolotl and Xenopus. However, glutamate-cysteine ligase modifier subunit was down regulated in axolotl and up regulated in Xenopus. Thus, < $5 \%$ of the 'core' DEGs that are commonly expressed among Xenopus tissues during metamorphosis, were identified as DEGs in our study using axolotl.

We also conducted a comprehensive bioinformatics comparison between DEGs from axolotl epidermis and DEGs from $\mathrm{T}_{3}$ induced Xenopus intestine [10]. Gene expression similarities may exist between the Xenopus intestine and axolotl epidermis because both organs undergo extensive extracellular remodeling that is associated with apoptosis of larval epithelial cells and the proliferation and differentiation of adult cell types. The presumptive orthologs of 111 of the 820 non-redundant DEGs from our study correspond to DEGs from Xenopus intestine [see Additional files 13, 14]. Of these 111 genes, 50 (45\%) exhibited the same direction of differential expression in axolotl epidermis and Xenopus intestine. This list includes genes that are known to be associated with metamorphic developmental processes in amphibians. For example, two MMPs (MMP9 and MMP13) that are associated with extra cellular matrix turnover were up regulated in Xenopus intestine and axolotl epidermis. However, other genes were regu- lated in opposite directions. For example, keratin 12 and keratin 15 were down regulated in axolotl epidermis but up regulated in Xenopus intestine. These results show that there are similarities and differences in gene expression between Xenopus and axolotls when comparing tissues that undergo similar remodeling processes.

\section{Biological, technical, and statistical replication}

In order to validate a subset of genes that were identified as DEGs in our microarray experiment, we conducted a second experiment in which we used quantitative realtime reverse transcriptase polymerase chain reaction (QRT-PCR) to generate expression profiles for five candidate genes (Table 3 ). These genes were chosen because they are involved in a variety of biological processes including cytoskeleton organization (desmin), cell-cell adhesion (desmocollin 1), tissue remodeling (matrix metallopeptidase 13), and ion transport (solute carrier family 31 member 1). In addition, we investigated SRV_10216_s_at in order to verify results from a gene with unknown function. Results of the regression analyses performed on the Q-RT-PCR data are presented in Figure 5 alongside plots of the analogous microarray data. Residuals from the models fit for desmocollin 1 and solute carrier family 31 member 1 exhibited significant departures from normality (Shapiro-Wilk test, $P<0.05)$. Overall, there was very good agreement between the expression profiles obtained from microarray and Q-RT-PCR analyses. The fact that the Q-RT-PCR results are biologically and technically independent of the microarray data strongly suggests that these patterns are repeatable and unlikely to be experimental or technical artifacts. 
Table 3: Primer sequences used for Q-RT-PCR

\begin{tabular}{|c|c|c|c|}
\hline Gene & Symbol & Probe-set ID/Direction & Sequence \\
\hline \multirow[t]{2}{*}{ Desmin } & DES & SRV_0I373_at_5.I & GGGCCAATTATGAAGCAA \\
\hline & & SRV_0I373_at_3.I & CTTCGACGACTCGCTTTG \\
\hline \multirow{2}{*}{ Desmocollin I } & DSCI & SRV_04693_a_at_5.I & GAGTCATTGCTCTTCCTTGG \\
\hline & & SRV_04693_a_at_3.I & TTTTGATGTGCTGCTCCA \\
\hline \multirow[t]{2}{*}{ Matrix metallopeptidase 13} & MMPI3 & SRV_II423_at_5.I & TGGAAGAAGACTGCGTTGA \\
\hline & & SRV_II423_at_3.I & ACACTTTGAAGGCCCTTTG \\
\hline \multirow[t]{2}{*}{ Solute carrier family 31 member I } & SLC3IAI & SRV_0I2I5_a_at_5.I & TGTGATCAAACCCCAGGA \\
\hline & & SRV_01215_a_at_3.I & CGCGCAATCTTAAGGAAC \\
\hline \multirow[t]{2}{*}{ N/A } & N/A & SRV_10216_s_at_5.I & ACATCACTGTCCCCGAAGT \\
\hline & & SRV_I0216_s_at_3.I & GGTCGGGGTCTGTTCAAT \\
\hline
\end{tabular}

N/A refers to a gene that does not have an established orthology with human. Probe-set ID represents the unique identifier for each probe-set on the custom Ambystoma GeneChip. Forward and reverse primers are denoted by the extensions 5.I and 3.I respectively.

Previously, we used stringent statistical criteria (one-way ANOVA, FDR $=0.001$, and $\geq$ two-fold change) to identify 123 annotated genes that exhibited robust responses to 50 $\mathrm{nM} \mathrm{T}_{4}[11]$. In that study, we focused on the potential of several keratin loci to serve as biomarkers of early metamorphic changes that precede changes in gross morphology. In this study, we used less stringent criteria to identify DEGs and more fully explore temporal gene expression responses when $\mathrm{T}_{4}$ concentration is varied. Of the 123 DEGs previously identified in the epidermis of metamorphosing axolotls, 116 genes were statistically significant and differentially regulated by $\geq$ two-fold in the $50 \mathrm{nM}$ regression analysis. Of these, 91 (78\%) were statistically significant and differentially expressed by $\geq$ two-fold in the $5 \mathrm{nM}$ regression analysis. Only one of these 91 genes was expressed in opposite directions between the $\mathrm{T}_{4}$ treatments (3' repair exonuclease 2). However this gene was classified as LU in $5 \mathrm{nM} \mathrm{T}_{4}$ and QLCD in $50 \mathrm{nM} \mathrm{T}_{4}$, and represents another example of a transiently up regulated gene that was categorized as QLCD [see Additional files 7, 8]. The 25 genes identified in $50 \mathrm{nM} \mathrm{T}_{4}$ but not $5 \mathrm{nM} \mathrm{T}_{4}$ (Table 4) may function in late stage metamorphic processes that were only attained within 28 days under $50 \mathrm{nM}$ $\mathrm{T}_{4}$. For example, keratin 17 is known to be a marker of proliferating basal epidermal stem cells in mammals [21]; this gene may be expressed late during metamorphosis in terminal cell populations of axolotl epidermis that give rise to adult epithelial cells. Other genes associated with tissue stress, injury, and immune function (ferritin heavy polypeptide 1, ras-related C3 botulinum toxin substrate 2, and cathespin $S$ ) also appear to be late response genes although we can't rule out the possibility that these genes may be differentially expressed as a toxic response to $50 \mathrm{nM} \mathrm{T}_{4}$. The majority of the DEGs identified previously using 50 $\mathrm{nM} \mathrm{T}_{4}$ and very strict statistical criteria were similarly identified using $5 \mathrm{nM} \mathrm{T}_{4}$ and different statistical methods/criteria. These findings further emphasize that the metamorphic gene expression programs of A. mexicanum are similar even when $\mathrm{TH}$ concentration is varied by an order of magnitude.

\section{Discussion}

Paedomorphic Mexican axolotls can be induced to undergo metamorphosis by administering TH. We found that axolotls initiate metamorphosis at least one week earlier in $50 \mathrm{nM}$ versus $5 \mathrm{nM} \mathrm{T}_{4}$ and complete morphological transformations in 28 days. The lower $5 \mathrm{nM} \mathrm{T}_{4}$ concentration was sufficient to induce metamorphosis but the initiation timing was delayed and this proportionally delayed the time to complete metamorphosis. The same sequence of morphological changes was observed between $\mathrm{T}_{4}$ treatments and the majority of DEGs were identified in both $\mathrm{T}_{4}$ treatments, although their expression profiles were temporally shifted. Nearly all DEGs exhibited similar directional trends between treatments, and the subset of genes that were directly compared between the $\mathrm{T}_{4}$ treatments exhibited similar relative abundances. Our results show extremely similar changes in gene expression and morphology in the axolotl when varying $\mathrm{T}_{4}$ by an order of magnitude. This is an interesting result because $\mathrm{T}_{4}$ concentrations within this range are toxic to anurans and are known to affect tissue-specific abundances of transcription factors that regulate metamorphic gene expression programs [16]. Below, we discuss the axolotl's precise transcriptional response to the range of $\mathrm{T}_{4}$ concentrations examined in this study. We then discuss the epidermal gene expression program of the axolotl, noting gene expression similarities and differences between salamander and anuran metamorphosis.

$\mathrm{TH}$ levels are known to increase in larval amphibians as they mature and reach maximal levels during metamorphic climax. When the concentration of TH reaches a critical intracellular level, transcriptional changes are initiated that bring about new patterns of development. Because the $\mathrm{TH}$ concentration required to alter transcription is cell-specific, tissues are often described as having 


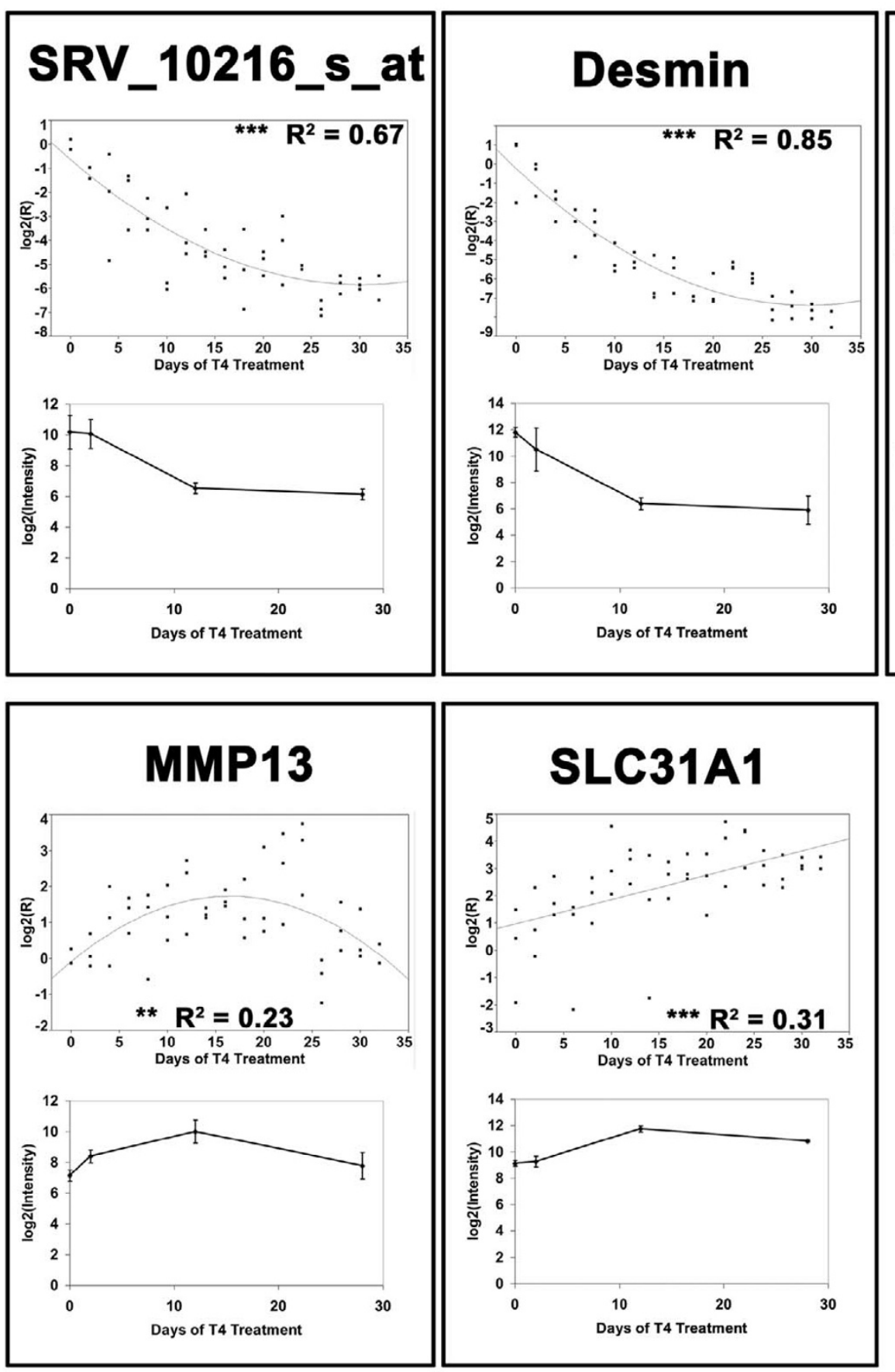

\section{Desmocollin 1}
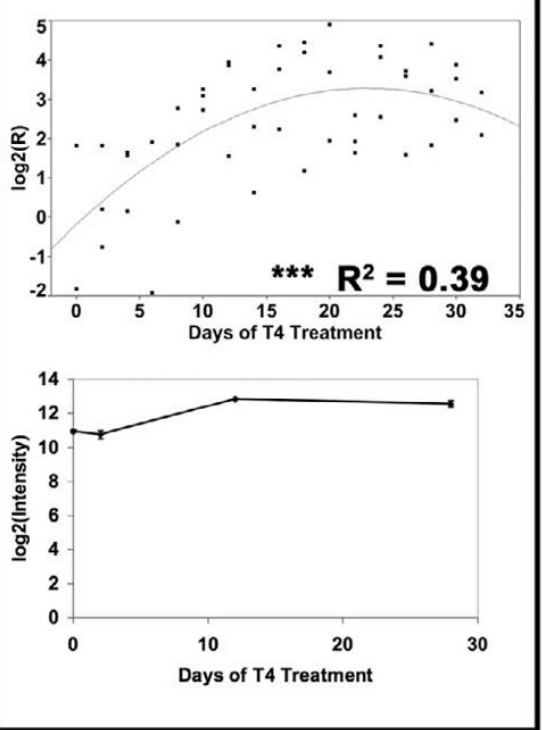

Figure 5

Comparison of Q-RT-PCR and microarray data. Comparisons of the relationships between transcript abundance and days of $50 \mathrm{nM} \mathrm{T}_{4}$ treatment as assessed in different biological samples via Q-RT-PCR (upper panels) and Affymetrix GeneChip technology (lower panels). Trend lines in the Q-RT-PCR data were obtained by linear or quadratic regression. Models with $P<$ 0.01 are denoted by ** and models with $P<0.0001$ are denoted by ***. $\mathrm{R}^{2}$ refers to adjusted $R^{2}$. The microarray data represent the mean of three samples \pm standard deviation. MMPI $3=$ matrix metallopeptidase $I 3$ and SLC $3 \mid \mathrm{AI}=$ solute carrier family $3 \mathrm{I}$, member 1 . 
Table 4: Genes previously identified using $50 \mathrm{nM} \mathrm{T}_{4}$ that were not identified using $5 \mathrm{nM} \mathrm{T}_{4}$

\begin{tabular}{|c|c|c|}
\hline Gene & Probe-set ID & Profile \\
\hline Actin alpha 2 & SRV_01045_a_at & LU \\
\hline Actin alpha 2 & SRV_III52_at & LU \\
\hline Cathepsin S & SRV_02072_at & QLCD \\
\hline Chormosome 20 open reading frame 92 & SRV_05090_at & QLVD \\
\hline Chromosome 21 open reading frame 33 & SRV_02285_at & QLCD \\
\hline Cytochrome $C$ oxidase subunit VIB polypeptide I & SRV_01220_at & QLCD \\
\hline Cytochrome P450 family 2 subfamily c polypeptide 8 & SRV_00512_at & QLCD \\
\hline EPH receptor $A I$ & SRV_12195_at & QC \\
\hline Eukaryotic translation initiation factor $4 E$ binding protein 3 & SRV_01958_at & QV \\
\hline Ferritin heavy polypeptide I & SRV_0I294_at & QLCD \\
\hline Glutaredoxin & SRV_0I306_at & LD \\
\hline Glycine C-acetyltransferase & SRV_0349I_a_at & LU \\
\hline High-mobility group $20 \mathrm{~A}$ & SRV_04I8I_at & QLVD \\
\hline Hypothetical protein FLIIII5I & SRV_04229_at & QLVU \\
\hline Keratin 17 & SRV_00389_a_at & QLCD \\
\hline LSMIO U7 small nuclear RNA associated & SRV_05010_at & QLVD \\
\hline Mediator of RNA polymerase II transcription subunit 3 I homolog & SRV_03843_a_at & QLVD \\
\hline Myosin heavy polypeptide II & SRV_II44I_at & LU \\
\hline Myosin light polypeptide 9 & SRV_12418_at & LU \\
\hline Nick-associated protein I & SRV_03398_at & LU \\
\hline Non-metastatic cells 7 & SRV_03369_at & QLVD \\
\hline P450 oxidoreductase & SRV_00555_at & LU \\
\hline Phosphoglucomutase 2 & SRV_04215_at & QLVU \\
\hline Ras-related C3 botulinum toxin substrate 2 & SRV_01633_at & QLCD \\
\hline Ubiquitin specific peptidase 10 & SRV_0246I_at & QLCU \\
\hline
\end{tabular}

Probe-set ID represents the unique identifier for each probe-set on the custom Ambystoma GeneChip. Profile refers to the regression profile obtained from the regression analysis of the $50 \mathrm{nM} \mathrm{T}_{4}$ dataset. $\mathrm{LU}=$ linear up, $\mathrm{QLCD}=$ quadratic linear concave down, $\mathrm{QC}=$ quadratic concave, $\mathrm{QV}=$ quadratic convex, $\mathrm{QLVD}=$ quadratic linear convex down, $\mathrm{LD}=$ linear down, $\mathrm{QLCU}=$ quadratic linear concave up, and $\mathrm{QLVU}=$ quadratic linear convex up.

different sensitivities to TH. The sensitivity of cells to TH involves multiple factors that affect the intracellular concentration of TH and the ability of TH to affect transcription, which is determined in part by the number of nuclear TH binding sites (TRs) [22]. Mexican axolotls have functional TRs [23], but TH levels are apparently too low to initiate metamorphosis [24]. Direct hypothalamic application of $\mathrm{T}_{4}$, using a dose that is insufficient to initiate metamorphosis via intraperitoneal injection, is sufficient to initiate metamorphosis in the axolotl [7] and related paedomorphic tiger salamanders [25]. Thus, axolotls are capable of synthesizing TH in sufficient quantities to initiate and complete metamorphosis. However, the pituitary doesn't release a sufficient amount of thyrotropin to trigger the metamorphic process [24]. Axolotl epidermis can be stimulated to initiate metamorphic changes in vitro, in isolation of endogenously synthesized TH [26]. Thus, the metamorphic timing delay that we observed between the 5 and $50 \mathrm{nM} \mathrm{T}_{4}$ treatments probably reflects the time required to autonomously activate gene expression within TH responsive cells of the epidermis and the time required to stimulate the HPT axis. Rosenkilde [27] showed that this latency period is $\mathrm{TH}$ concentration dependent and above a critical dose $\left(37.5 \mathrm{nM} \mathrm{T}_{3}\right)$ there is no variation in latency. After accounting for an estimated one-week difference in the initiation timing of metamorphosis between the $\mathrm{T}_{4}$ treatments, there was not a difference in the length of the metamorphic period. Thus, endogenous TH levels were functionally, if not quantitatively similar between 5 and $50 \mathrm{nM} \mathrm{T}_{4}$ treated axolotls after metamorphosis was initiated. This idea is also supported by the precise gene expression response that we observed between the $\mathrm{T}_{4}$ treatments: essentially all of the genes were expressed in the same direction, and a subset of genes that could be reliably compared showed the same magnitude of gene expression.

The precision of the transcriptional response between $T_{4}$ treatments indicates that axolotls are surprisingly tolerant to $T_{4}$ levels that dramatically affect anuran mortality and gene expression. Others before us have also noted the tolerance of axolotls to high levels of $\mathrm{T}_{4}[27,28]$. Because anuran metamorphosis involves a more extensive and integrated set of remodeling events that are accomplished over a shorter time frame, there may be greater overlap in the sensitivities of cells to TH among tissues that causes metamorphic remodeling events to occur out of sequence. The fact that salamander metamorphosis encompasses 
fewer morphological changes and that many of the changes are not as integrated (hindlimb development occurs months before tail metamorphosis) may explain why axolotls are so tolerant to high $\mathrm{T}_{4}$ concentrations. However, failure to observe an increase in thyroid hormone receptor beta transcription in axolotl suggests there may be fundamental regulatory differences between anuran and salamander metamorphosis.

The larval epidermis of axolotls is extensively remodeled during $\mathrm{T}_{4}$ induced metamorphosis [29-31]. Application of $\mathrm{TH}$ to paedomorphic axolotls induces many of the same epidermal changes that occur during natural and induced metamorphosis in anurans, including apoptosis of larval cells, proliferation of adult cell types, and epidermal keratinization. Our results show that TH induces a diversity of transcriptional changes that are associated with specific remodeling processes. We observed significant gene expression changes between the $\mathrm{T}_{4}$ treatments at Day 2, prior to observable morphological changes at the wholeorganism level. Most of these genes were up regulated in the higher $\mathrm{T}_{4}$ concentration relative to the lower $\mathrm{T}_{4}$ concentration. Day 2 gene expression changes may reflect direct transcriptional activation via the binding of exogenous TH to TRs, which are functional in axolotls [23]. For example, the human ortholog of phosphoenolpyruvate carboxykinase 1, a primary target for transcriptional regulation of gluconeogenesis, is known to have a thyroid hormone response element [32]. Early up regulation of phosphoenolpyruvate carboxykinase 1, as well as fructose 1,6 bisphosphotase, glucose 6 phosphate dehydrogenase, and $70 \mathrm{kD}$ heat shock protein 5 at Day 12, indicates a biochemical response at the cellular level that includes activation of key regulatory enzymes of the gluconeogenic pathway. This is an interesting finding for the epidermis because such responses are generally associated with hepatic cell functions. Several other interesting gene expression changes were detected at Day 2 . These include ATP binding cassette, subfamily B, member 4, and transglutaminase 1. ATP binding cassette family genes are up regulated in mammals during epidermal lipid reorganization and keratinocyte differentiation [33], and transglutaminase 1 encodes an enzyme that functions in the formation of the cross-linked, cornified envelop of keratinocytes [34]. The early expression of these genes is curious because keratinization is assumed to be a terminal differentiation event in the metamorphosis of amphibian epidermis. Our results suggest that the process of keratinization is initiated very early. As a final example, two proteins that are specific to the mammalian inner ear were identified as significantly down regulated: otogelin and otoancorin. The head epidermis of the axolotl contains mechanoreceptors that are homologous to hair cells of the mammalian ear [35]. Our results suggest remodeling of these and other neural components in the axolotl skin at metamorphosis. There are many additional examples that could be highlighted from our gene lists that have not been previously discussed within the context of amphibian metamorphosis.

The most gene expression changes and the greatest changes in transcript abundances were observed at Day 12 in $50 \mathrm{nM} \mathrm{T}_{4}$. For example, keratin 14, a prototypical marker of proliferating keratinocytes in mammals [36], was up regulated 1146 fold in $50 \mathrm{nM} \mathrm{T}_{4}$. This also marks the time of the greatest morphological remodeling. After this time, gene expression levels of many genes decreased. Thus, as has been described in anurans, many gene expression changes in axolotl are transient, increasing initially and then decreasing. For example, apoptosis is activated and terminated during anuran [37] and salamander [38] metamorphosis to regulate the death and replacement of larval epithelial cells. When statistically significant genes were analyzed in the absence of a two-fold change criterion, genes that were transiently up regulated (i.e., exhibited QC profiles) were statistically associated with apoptosis and proteolysis functional ontologies (data not shown). As another example of the similarities between the metamorphic gene expression changes that occur in the epidermis of frogs and salamanders, we identified three distinct probe-sets with established orthologies to human uromodulin that are dramatically down regulated in the epidermis of metamorphosing A. mexicanum. Furlow et al. [39] have observed analogous results in X. laevis and have shown that Xenopus uromodulin orthologs are exclusively expressed in the apical cells of the larval epidermis. These and other genes that are similarly expressed between urodeles and anurans will provide useful biomarkers for comparative studies of metamorphosis between these two groups.

Our informatics comparison between DEGs identified from axolotl epidermis and Xenopus intestine identified > 100 genes that are commonly expressed in these organs during metamorphic remodeling. However, over half of these genes were differentially expressed in opposite directions in axolotl and Xenopus. For example, several genes associated with immune function (CD74 antigen, chemokine ligand 5, interferon regulatory factor 1, proteasome beta subunit 9, and class I-related major histocompatability complex) were down regulated in axolotl epidermis and up regulated in Xenopus intestine. This is not too surprising because it is well established that the axolotl immune system is fundamentally different from that of other vertebrates, including Xenopus [40]. Additionally, genes expressed in opposite directions in these comparisons may reflect fundamental differences that exist between intestinal and epidermal remodeling. Genes that exhibited similar transcriptional patterns between Xenopus intestine and axolotl epidermis were associated with many different functions. For example, DNA methyltrans- 
ferase 1 and 17-beta hydroxysteroid dehydrogenase 8 were down regulated in axolotl epidermis and Xenopus intestine during induced metamorphosis. In mammals, DNA methyltransferase 1 functions to maintain DNA methylation patterns that influence gene transcription [41] and 17-beta hydroxysteroid dehydrogenase 8 preferentially inactivates androgens and estrogens, $[42,43]$. This later example suggests a transcriptional response to increase gonadal steroid hormone levels during epithelial remodeling in amphibians. As a final example, a presumptive ortholog to human keratin 24 (SRV_13498_s_at) that was up regulated by $>1000$ fold in axolotls exposed to $50 \mathrm{nM} \mathrm{T}_{4}$ was also up regulated in Xenopus intestine, albeit by a comparatively modest four-fold increase. These comparisons emphasize similarities and differences in gene expression during metamorphic epithelial tissue remodeling in anurans and salamanders.

\section{Conclusion}

Recent microarray analyses of anurans and salamanders show that amphibian metamorphosis involves thousands of gene expression changes, involving many biological processes that have previously received little attention $[9,10]$. Our results show similarities and differences in the metamorphic transcriptional programs of anurans and salamanders. We expected to identify similarly expressed genes because epidermis was included in anuran tissue preparations that were used for microarray analysis, and because tissue remodeling that occurs during metamorphosis appears to involve some evolutionarily conserved biological processes. We also expected to observe transcriptional differences because anuran and salamander lineages diverged $>300$ million years ago. Our results suggest that amphibian metamorphosis cannot be fully understood from the study of a few anuran species. We show here that axolotls offer several advantages (inducible metamorphosis, robust transcriptional response, less complex integration of remodeling events) that can be exploited to provide complementary and novel perspectives on amphibian metamorphosis.

\section{Methods}

Study animals for microarray analyses

All procedures were conducted in accordance with the University of Kentucky Animal Care and Use Guidelines (IACUC \#00609L2003). Salamanders (A. mexicanum) were obtained from a single genetic cross, using adults from an inbred strain. Embryos and larvae were reared individually at 20-22 C in 40\% Holtfreter's solution. After hatching, larvae were fed freshly hatched brine shrimp (Artemia sp., Brine Shrimp Direct, Ogden, UT) napuli until they were large enough ( 3 weeks) to eat California blackworms (Lumbriculus sp., J.F. Enterprises, Oakdale, CA). At approximately eight months of age, 30 salamanders were randomly assigned to each of 10 different treat- ments and reared in $40 \%$ Holtfreter's solution with or without $\mathrm{T}_{4}$, (Sigma T2376, St. Louis, MO). One hundred $\mu \mathrm{M}$ stock $\mathrm{T}_{4}$ solutions were made as described in Page et al. [11]. Five and $50 \mathrm{nM} \mathrm{T}_{4}$ were made fresh for each water change by mixing 2.5 or $25 \mathrm{~mL}$ of $100 \mu \mathrm{M}$ stock with $40 \%$ Holfreter's solution to a final volume of $50 \mathrm{~L}$. Water was changed every third day.

Skin tissue was collected from salamanders following 0,2 , 12 , and 28 days of $\mathrm{T}_{4}$ treatment. These time points were sampled to test for early gene expression changes that might precede morphological metamorphosis, and because 28 days is a sufficient period for complete metamorphosis of $50 \mathrm{nM} \mathrm{T}_{4}$ induced A. mexicanum [11]. To obtain tissue, salamanders were anesthetized in $0.01 \%$ benzocaine (Sigma, St. Louis, $\mathrm{MO}$ ) and $\approx 1 \mathrm{~cm}^{2}$ of skin tissue was removed from the top of the head.

\section{RNA isolation}

Total RNA was extracted for each tissue sample with TRIzol (Invitrogen, Carlsbad, CA) according to the manufacturer's protocol; additionally, RNA preparations were further purified using a Qiagen RNeasy mini column (Qiagen, Valencia, CA). UV spectrophotometry and a 2100 Agilent Bioanalyzer (Agilent Technologies, Santa Clara, CA) were used to quantify and qualify RNA preparations. Three high quality RNA isolations from each treatment and sampling time combination were used to make individual-specific pools of biotin labeled cRNA probes. Each of the 30 pools was subsequently hybridized to an independent GeneChip. The University of Kentucky Microarray Core Facility generated cRNA probes and performed hybridizations according to standard Affymetrix protocols.

\section{Microarray platform}

A custom Ambystoma Affymetrix (Santa Clara, CA) GeneChip was designed from curated expressed sequence tag assemblies for $A$. mexicanum and A. tigrinum $[44,45]$. The array contains 4844 probe-sets, 254 of which are controls or replicate probe-sets. Detailed descriptions of this microarray platform can be found in Page et al. [11] and Monaghan et al. [46].

\section{Quality control and low-level analyses}

We used the Bioconductor package affy [47] that is available for the statistical programming environment $R$ [48] to perform a variety of quality control and preprocessing procedures at the individual probe level $[49,50]$. These procedures included: 1 ) generating matrices of $M$ versus $A$ plots for all replicate GeneChips ( $n=3$ GeneChips for 10 treatment/sampling time combinations), 2) investigating measures of central tendency, measures of dispersion, and the distributions of all 30 GeneChips via boxplots and histograms, 3 ) viewing images of the $\log _{2}$ (intensity) val- 
ues for each GeneChip to check for spatial artifacts, and 4) viewing an RNA degradation plot [50] that allows for visualization of the 3' RNA labeling bias across all GeneChips simultaneously. In addition, we used ArrayAssist Lite software (Stratagene, La Jolla, CA) to assess several quality control measures that are recommended by Affymetrix such as average background (minimum = 48.36, maximum $=59.28, n=30$ ) scale factors (minimum $=0.404$, maximum $=0.629, n=30)$, and percent present $($ minimum $=81.5$, maximum $=86.5, n=30)$. Next, we processed our data by implementing the robust multiarray average (RMA) algorithm of Irizarry et al. [51].

\section{Assessment of GeneChip precision}

To obtain estimates of between GeneChip repeatability, we generated correlation matrices for the hybridization intensities across all probe-sets among replicate GeneChips. Very high and consistent mean $r$-values were calculated for each of the 10 treatment by sampling time combinations (range of mean $r \pm$ standard error $=0.966 \pm$ 0.002 to $0.986 \pm 0.001)$. These results demonstrate that we were able to obtain a high level of repeatability between replicate GeneChips. Our data are MIAME compliant and raw data files can be obtained at Sal-Site $[45,52]$.

\section{Data filtering}

Microarray platforms may not accurately or precisely quantify genes with low intensity values $[53,54]$. Because low intensity genes contribute to the multiple testing problem that is inherent to all microarray studies, we filtered probe-sets whose mean expression values across all GeneChips ( $n=30$ per gene) were smaller than or equal to the mean of the lowest quartiles $\left(25^{\text {th }}\right.$ percentiles) across all GeneChips $(n=30$, mean $=6.53$, standard deviation $=0.04$; data presented on a $\log _{2}$ scale). Upon performing this filtration step, 3688 probe-sets were available for significance testing. We then performed PCA on the centered and scaled data from these probe-sets. This analysis allowed us to visualize the relationships between GeneChips within and across treatments.

\section{Temporal gene expression in the absence of $T_{4}$}

We investigated whether genes exhibited differential expression as a function of time in the absence of $\mathrm{T}_{4}$ (control animals sampled at Days 0,2,12, and 28) via linear and quadratic regression [55]. We corrected for multiple testing by evaluating $\alpha_{0}$ according to the algorithm of Benjamini and Hochberg [56] with a FDR of 0.05. $\alpha_{1}$ was set to 0.05 .

\section{Detecting and classifying DEGs}

We conducted three analyses to investigate the effect of $\mathrm{T}_{4}$ on epidermal gene expression. For the first analysis, we used limma $[57,58]$ to identify genes that were differen- tially expressed as a function of $\mathrm{T}_{4}$ concentration. The limma package couples linear models with an empirical Bayes methodology to generate moderated $t$-statistics for each contrast of interest. This approach has the same effect as shrinking the variance towards a pooled estimate and thus reduces the probability of large test statistics arising due to underestimations of the sample variances. Operating limma requires the specification of two matrices. The first is a design matrix in which the rows represent arrays and the columns represent coefficients in the linear model. The second is a contrast matrix in which the columns represent contrasts of interest and the rows represent coefficients in the linear model. For this analysis, the design matrix specified a coefficient for each unique treatment by sampling time combination (10 coefficients) and the contrast matrix specified the calculation of contrasts between the two $\mathrm{T}_{4}$ concentrations ( 5 and $50 \mathrm{nM}$ ) at each of the non-zero sampling times (Days: 2, 12, and 28). In addition to moderated $t$-statistics, limma also generates moderated F-statistics. These moderated F-statistics test the null hypothesis that no differences exist among any of the contrasts specified by a given contrast matrix. A FDR correction [56] of 0.05 was applied to the $P$-values associated with the moderated $F$-statistics of the contrast matrix. In order to further reduce the number of false positives, we required that all "identified" DEGs be differentially regulated by $\geq$ two-fold at one or more of the contrasted time points.

The last two analyses were conducted using the regressionbased approach of Liu et al. [55] to detect genes that exhibit differential expression as a function of days of $\mathrm{T}_{4}$ treatment. This approach also classifies DEGs into nine categories based on their temporal expression profiles as determined via linear and quadratic regression. In the context of our experiment, these profiles have specific biological interpretations. However, exceptions to these interpretations exist (see results for examples). In general, genes that exhibited LD, LU, QLCD, and QLVU expression profiles were still actively undergoing changes in their expression levels when the study was terminated. In contrast, genes that exhibited QLVD and QLCU expression profiles underwent down and up regulation respectively but reached steady state expression levels before the experiment was terminated. Finally, genes that exhibited QC and QV expression profiles were transiently up and down regulated respectively before returning to baseline expression levels. Null results are described by the 'Flat' category. Separate analyses were conducted for the 5 and $50 \mathrm{nM}$ datasets with $\alpha_{0}$ evaluated at a FDR of 0.05 according to the algorithm of Benjamini and Hochberg [56] and $\alpha_{1}=$ 0.05 . DEGs were required to exhibit $\geq$ two-fold changes relative to Day 0 controls at one or more sampling times before they were categorized as "identified". 


\section{Over representation analyses for genes with established orthologies}

Biological process gene ontology categories that are over represented in our lists of DEGs (statistically significant and $\geq$ two-fold change) were identified using the Database for Annotation Visualization and Integrated Discovery (DAVID) [59]. In all analyses, the 3085 probe-sets on the Ambystoma GeneChip with established orthologies were used as the background for generating expected values. The EASE threshold was always set to 0.05 , and the count threshold was always set to two.

\section{Bioinformatic comparison with Xenopus}

In a recent microarray study, Buchholz et al. [10] presented "a core set of up regulated genes". These genes have been identified as up regulated in response to $\mathrm{T}_{3}$ treatment by $\geq 1.5$ fold in every tissue that has been examined in metamorphosing $X$. laevis via microarray analysis (limb, brain, tail, and intestine) $[9,10]$. We determined the orthologies of these genes to human as described in Page et al. [11] and Monaghan et al. [46]. We then identified genes listed by Buchholz et al. [10] that were also differentially expressed in our experiment. The same approach was used to compare our gene lists to the 2340 DEGs identified by Buchholz et al. [10] from the intestine of metamorphosing $X$. laevis.

\section{Biologically and technically independent verification}

We conducted a second experiment using Q-RT-PCR to investigate the temporal expression patterns of five genes identified as differentially expressed by microarray analysis (Table 3). Animals used in our second experiment were raised as described for the animals used in the microarray experiment, with the exception that $\mathrm{T}_{4}$ treatment (50 nM) was initiated at 120 days post-fertilization. Tissue samples from two or three individuals were collected as described above beginning on Day 0 (prior to initiating $\mathrm{T}_{4}$ treatment) and were collected every two days for 32 days (i.e., Day 0, Day 2, Day 4... Day 32).

\section{Q-RT-PCR}

Total RNA was extracted from integument as described for the microarray experiment with the exception that all samples were treated with RNase-Free DNase Sets (Qiagen, Valencia, CA) according to the manufacturer's protocol. For each sample, the Bio-Rad iScript cDNA synthesis kit (Hercules, CA) was used to synthesize cDNA from $1 \mu \mathrm{g}$ total RNA. Primers (Table 3 ) were designed using Primer3 [60], and design was targeted to the same gene regions that are covered by Affymetrix probe-sets. All PCRs were $25 \mu \mathrm{L}$ reactions that contained: cDNA template corresponding to $10 \mathrm{ng}$ total RNA, $41 \mathrm{ng}$ forward and reverse primers, and iQ SYBR-Green real-time PCR mix (Bio-Rad, Hercules, CA). Reaction conditions were as follows: 10 minutes at $50 \mathrm{C}$, five minutes at $95 \mathrm{C}, 45$ cycles of $10 \mathrm{sec}-$ onds at $95 \mathrm{C}$ followed by 30 seconds at $55 \mathrm{C}$, one minute at $95 \mathrm{C}$, and one minute at $55 \mathrm{C}$. Melting curve analysis was used to ensure the amplification of a single product for each reaction. All reactions were run in 96 well plates and blocked by sampling time (i.e., each of the 17 sampling times was equally represented for each gene on each plate). PCRs were performed using a Bio-Rad iCycler iQ Multi-Color Real Time PCR Detection System (Hercules, CA). All plates contained template free controls [61]. Primer efficiencies were estimated via linear regression and relative expression ratios $(\mathrm{R})$ were calculated according to Pfaffl [62]. All expression ratios are relative to the average of the Day 0 animals, and normalized to transcriptional intermediary factor 1 (probe-set ID: L_s_at). This gene was selected as a control because it had an extremely small standard deviation across all treatment regimes in the microarray experiment $(n=30$, mean $=14.44$, standard deviation $=0.03$; data presented on a $\log _{2}$ scale) .

\section{Statistical Analysis of the Q-RT-PCR Data}

$\log _{2}$ transformed R-values for each gene were analyzed separately via linear and quadratic regression models in which days of $\mathrm{T}_{4}$ treatment was the predictor variable. These analyses were carried out using JMP, Version 5 (SAS Institute, Cary, NC). We decided whether to use a linear or quadratic model for a given gene via forward selection [20]. In short, quadratic models were accepted when the polynomial terms were significant $(P<0.05)$ and resulted in an increase in the proportion of variation in the data explained by the model (adjusted $R^{2}$ ) of $\geq$ five percent relative to the linear model. The residuals of all models were inspected graphically. In addition, the residuals of all models were checked for normality. In cases where the assumption of normality was violated, regression analyses were run to obtain equations that describe the response of these genes to $\mathrm{T}_{4}$ as a function of time. However, such analyses were conducted with the understanding that a strict hypothesis testing interpretation could prove problematic.

\section{Authors' contributions}

RBP carried out statistical and informatic analyses, conducted the Q-RT-PCR experiment, and helped draft the paper. SRV conceived the research project, provided general oversight for the project, and participated in drafting the manuscript. AKS reared the animals associated with the microarray experiment, collected tissue, and extracted RNA. JJS participated in rearing the animals associated with the microarray experiment and contributed to the statistical analyses that were conducted. SP conducted the informatic analyses used to determine the presumptive orthologies of Xenopus genes to human. CKB helped conceive the project, participated in coordinating the project, and provided critical reviews of the manuscript. All 
authors have read and approved the final version of this manuscript.

\section{Additional material}

\section{Additional file 1}

Analysis of the effect of time in the absence of $T_{4}$. Excel table containing statistical and informatic values associated with the analysis of the effect of time in the absence of $T_{4}$.

Click here for file

[http://www.biomedcentral.com/content/supplementary/14712164-9-78-S1.xls]

\section{Additional file 2}

Description of the effect of time in the absence of $\mathrm{T}_{4}$. Word document containing descriptions of the column headers in Additional file 1.

Click here for file

[http://www.biomedcentral.com/content/supplementary/1471-

2164-9-78-S2.doc]

\section{Additional file 3}

DEGs identified by contrasting the $T_{4}$ concentrations at each non-zero time point. Excel table containing statistical and informatic values for the DEGs identified by contrasting the 5 and $50 \mathrm{nM} \mathrm{T}_{4}$ treatments at Days 2, 12 , and 28 and imposing fold change criteria.

Click here for file

[http://www.biomedcentral.com/content/supplementary/14712164-9-78-S3.xls]

\section{Additional file 4}

Description of the DEGs identified by contrasting the $T_{4}$ concentrations at each non-zero time point. Word document containing descriptions of the column headers in Additional file 3.

Click here for file

[http://www.biomedcentral.com/content/supplementary/1471-

2164-9-78-S4.doc]

\section{Additional file 5}

DEGs identified by the $5 \mathrm{nM}$ regression analysis. Excel table containing statistical and informatic values for the DEGs identified by conducting linear and quadratic regression on the $5 \mathrm{nM}$ dataset and imposing fold change criteria.

Click here for file

[http://www.biomedcentral.com/content/supplementary/1471-

2164-9-78-S5.xls]

\section{Additional file 6}

Description of the DEGs identified by the $5 \mathrm{nM}$ regression analysis. Word document containing descriptions of the column headers in Additional file 5.

Click here for file

[http://www.biomedcentral.com/content/supplementary/14712164-9-78-S6.doc]

\section{Additional file 7}

DEGs identified by the $50 \mathrm{nM}$ regression analysis. Excel table containing statistical and informatic values for the DEGs identified by conducting linear and quadratic regression on the $50 \mathrm{nM}$ dataset and imposing fold change criteria.

Click here for file

[http://www.biomedcentral.com/content/supplementary/1471-

2164-9-78-S7.xls]

\section{Additional file 8}

Description of the DEGs identified by the $50 \mathrm{nM}$ regression analysis. Word document containing descriptions of the column headers in Additional file 7 .

Click here for file

[http://www.biomedcentral.com/content/supplementary/14712164-9-78-S8.doc]

\section{Additional file 9}

The 79 genes unique to the $5 \mathrm{nM}$ regression analysis. Excel table containing statistical and informatic values for the 79 DEGs identified by the 5 $n M$ regression analysis and fold change criteria that were not identified by the $50 \mathrm{nM}$ regression analysis.

Click here for file

[http://www.biomedcentral.com/content/supplementary/1471-

2164-9-78-S9.xls]

\section{Additional file 10}

Description of the 79 genes unique to the $5 \mathrm{nM}$ regression analysis. Word document containing descriptions of the column headers found in Additional file 9.

Click here for file

[http://www.biomedcentral.com/content/supplementary/1471-

2164-9-78-S10.doc]

\section{Additional file 11}

The 246 genes unique to the $50 \mathrm{nM}$ regression analysis. Excel table containing statistical and informatic values for the 246 DEGs identified by the $50 \mathrm{nM}$ regression analysis and fold change criteria that were not identified by the $5 \mathrm{nM}$ regression analysis.

Click here for file

[http://www.biomedcentral.com/content/supplementary/1471-

2164-9-78-S11.xls]

\section{Additional file 12}

Description of the 246 genes unique to the $50 \mathrm{nM}$ regression analysis. Word document containing descriptions of the column headers found in Additional file 11.

Click here for file

[http://www.biomedcentral.com/content/supplementary/1471-

2164-9-78-S12.doc]

\section{Additional file 13}

The 111 genes identified as differentially expressed in axolotl epidermis and Xenopus intestine. Excel table containing statistical and informatic values for the genes identified as differentially expressed in axolotl epidermis and Xenopus intestine.

Click here for file

[http://www.biomedcentral.com/content/supplementary/1471-

2164-9-78-S13.xls] 


\section{Additional file 14}

Description of the 111 genes identified as differentially expressed in axolotl epidermis and Xenopus intestine. Word document containing descriptions of the column headers in Additional file 13.

Click here for file

[http://www.biomedcentral.com/content/supplementary/14712164-9-78-S14.doc]

\section{Acknowledgements}

Aspects of this project were supported by IBN-0242833 from the National Science Foundation (NSF) CAREER Award program and Grant Number 5 R24-RR016344-06 from the National Center for Research Resources (NCRR), a component of the NIH. Additional support for this research came from NIH Grant Numbers P20RR-01674I and P20RR-1648I from the INBRE Program of NCRR. The content of this study is solely the responsibility of the authors and does not necessarily represent the official views of NCRR or NIH or NSF. We thank Donna Walls and the University of Kentucky Microarray Core Facility for processing the GeneChips associated with this study. Arnold Stromberg provided statistical advice during the preparation of this manuscript.

\section{References}

I. Leloup J, Buscaglia M: La triiodothyronine: hormone de la metamorphose des amphibiens. CR Acad Sci 1977, 284:226I-2263.

2. Larras-Regard E, Taurog A, Dorris $M$ : Plasma $\mathbf{T}_{4}$ and $\mathbf{T}_{3}$ levels in Ambystoma tigrinum at various stages of metamorphosis. Gen Comp Endocrinol 1981, 43:443-450.

3. Tata JR: Requirement for RNA and protein synthesis for induced regression of the tadpole tail in organ culture. Dev Biol 1966, 13:77-94.

4. Shi YB: Amphibian Metamorphosis: From Morphology to Molecular Biology New York: Wiley-Liss; 2000.

5. Shaffer HB, Voss SR: Phylogenetic and mechanistic analysis of a developmentally integrated character complex: alternative life history modes in ambystomatid salamanders. Am Zool 1996, 36:24-35

6. Voss SR, Smith J]: Evolution of salamander life cycles: a majoreffect quantitative trait locus contributes to discrete and continuous variation for metamorphic timing. Genetics 2005, I 70:275-28I.

7. Rosenkilde P, Ussing AP: What mechanisms control neoteny and regulate induced metamorphosis in urodeles? Int J Dev Biol 1996, 40:665-673.

8. Kuhn ER, De Groef B, Van der Geyten S, Darras VM: Corticotropin-releasing hormone-mediated metamorphosis in the neotenic axolotl Ambystoma mexicanum : synergistic involvement of thyroxine and corticoids on brain type II deiodinase. Gen Comp Endocrinol 2005, I 43:75-8I.

9. Das B, Cai L, Carter MG, Piao YL, Sharov AA, Ko MSH, Brown DD Gene expression changes at metamorphosis induced by thyroid hormone in Xenopus laevis tadpoles. Dev Biol 2006, 29 I:342-355.

10. Buchholz DR, Heimeier RA, Das B, Washington T, Shi YB: Pairing morphology with gene expression in thyroid hormoneinduced intestinal remodeling and identification of a core set of TH-induced genes across tadpole tissues. Dev Biol 2007, 303:576-590.

II. Page RB, Monaghan JR, Samuels AK, Smith JJ, Beachy CK, Voss SR: Microarray analysis identifies keratin loci as sensitive biomarkers for thyroid hormone disruption in the salamander Ambystoma mexicanum. Comp Biochem Physiol C Toxicol Pharmacol 2007, | 45:15-27.

12. Wang Z, Brown DD: A gene expression screen. Proc Natl Acad Sc USA 1991, 88: II505-II509.

13. Buckbinder L, Brown DD: Thyroid hormone-induced gene expression changes in the developing frog limb. J Biol Chem 1992, 267:25786-2579|.
14. Shi YB, Brown DD: The earliest changes in gene expression in tadpole intestine induced by thyroid hormone. J Biol Chem 1993, 268:20312-20317.

I5. Denver RJ, Pavgi S, Shi YB: Thyroid hormone-dependent gene expression program for Xenopus neural development. J Biol Chem 1997, 272:8179-8I88.

16. Zhang F, Degitz SJ, Holcombe GW, Kosian PA, Tietge J, Veldhoen N Helbing CC: Evaluation of gene expression endpoints in the context of a Xenopus laevis metamorphosis-based bioassay to detect thyroid hormone disruptors. Aquat Toxicol 2006, 76:24-36.

17. Helbing CC, Bailey CM, Ji L, Gunderson MP, Zhang F, Veldhoen N, Skirrow RC, Mu R, Lesperance M, Holcombe GW, Kosian PA, Tietge J, Korte JJ, Degitz SJ: Identification of gene expression indicators for thyroid axis disruption in a Xenopus laevis metamorphosis screening assay part $\mathbf{I}$. effects on the brain. Aquat Toxicol 2007, 82:227-24I.

18. Helbing CC, Ji L, Bailey CM, Veldhoen N, Zhang F, Holcombe GW, Kosian PA, Tietge J, Korte JJ, Degitz SJ: Identification of gene expression indicators for thyroid axis disruption in a Xenopus laevis metamorphosis screening assay part 2. effects on the tail and hindlimb. Aquat Toxicol 2007, 82:215-226.

19. Cano-Martinez A, Vargas-Gonzalez A, Asai M: Metamorphic stages in Ambystoma mexicanum. Axolotl Newsletter 1994, 23:64-7I.

20. Zar JH: Biostatistical Analysis 4th edition. Upper Saddle River, NJ: Prentice Hall; 1999.

21. McGowan KM, Coulombe PA: Onset of keratin 17 expression coincides with the definition of major epithelial lineages during skin development. J Cell Biol 1998, I 43:469-486.

22. Yoshizato K, Frieden E: Increase in binding capacity for triiodothyronine in tadpole tail nuclei during metamorphosis. Nature 1975, 254:705-707.

23. Safi R, Bertrand S, Marchand O, Duffraisse M, de Luze A, Vanacker JM, Maraninchi M, Margotat A, Demeneix B, Laudet V: The axolotl (Ambystoma mexicanum), a neotenic amphibian, expresses functional thyroid hormone receptors. Endocrinology 2004, I 45:760-772.

24. Kuhn ER, Jacobs GFM: Metamorphosis. In Developmental Biology of the Axolotl Edited by: Armstrong JB, Malacinski GM. New York: Oxford University Press; 1989: 187-197.

25. Norris DO, Gern WA: Thyroxine-induced activation of hypothalamo-hyphophysial axis in neotenic salamander larvae. Science 1976, I 94:525-527

26. Takada $M$, Yai $H$, Komazaki S: Effect of calcium on development of amiloride-blockable $\mathrm{Na}^{+}$transport in axolotl in vitro. $\mathrm{Am} J$ Physiol 1998, 275:R69-R75.

27. Rosenkilde $P$ : The role of hormones in the regulation of amphibian metamorphosis. In Metamorphosis Edited by: Balls M, Bownes M. Oxford: Clarendon Press; 1985:221-259.

28. Brown DD: The role of thyroid hormone in zebrafish and axolotl development. Proc Natl Acad Sci USA I997, 94: $13011-13016$

29. Fahrmann W: Die morphodynamik der epidermis des axolotls (Sirendon mexcianum Shaw) unter dem einflub von exogen appliziertem thyroxin I. die epidermis des neotenen axolotls. Z Mikrosk Anat Forsch 1971, 83:472-506.

30. Fahrmann W: Die morphodynamik der epidermis des axolotls (Sirendon mexcianum Shaw) unter dem einflub von exogen appliziertem thyroxin II. die epidermis wahrend der metamorphose. Z Mikrosk Anat Forsch I97I, 83:535-568.

31. Fahrmann W: Die morphodynamik der epidermis des axolotls (Sirendon mexcianum Shaw) unter dem einflub von exogen appliziertem thyroxin III. die epidermis des metamorphosierten axolotls. Z Mikrosk Anat Forsch I97I, 84: I-25.

32. Giralt M, Park EA, Gurney AL, Liu J, Hakimi P, Hanson RW: Identification of a thyroid hormone response element in the phosphoenolpyruvate carboxykinase (GTP) gene. J Biol Chem I99I, 266:21991-21996.

33. Kielar D, Kaminski WE, Liebisch G, Piehler A, Wenzel J, Mohle C Heimerl S, Langmann T, Friedrich SO, Bottcher A, Barlage S, Drobnik W, Schmitz G: Adenosine triphosphate binding cassette (ABC) transporters are expressed and regulated during terminal keratinocyte differentiation: a potential role for ABCA7 in epidermal lipid reorganization. I Invest Dermatol 2003, I 2 I:465-474 
34. Hitomi K: Transglutaminases in skin epidermis. Eur J Dermatol 2005, I5:313-319.

35. Northcutt RG, Catania KC, Criley BB: Development of lateral line organs in the axolotl. J Comp Neurol 1994, 340:480-5 I4.

36. Coulombe PA, Kopan R, Fuchs E: Expression of keratin KI4 in the epidermis and hair follicle: insights into complex programs of differentiation. J Cell Biol 1989, 109:2295-23 I2.

37. Yoshizato K: Molecular mechanism and evolutional significance of epithelial-mesenchymal interactions in the body and tail-dependent metamorphic transformation of anuran larval skin. Int Rev Cytol 2007, 260:2 13-260.

38. Ohmura $\mathrm{H}$, Wakahara $\mathrm{M}$ : Transformation of skin from larval to adult types in normally and metamorphosis-arrested salamander, Hynobius retardatus. Differentiation 1998, 63(5):238-246.

39. Furlow JD, Berry DL, Wang Z, Brown DD: A set of novel tadpole specific genes expressed only in the epidermis are down-regulated by thyroid hormone during Xenopus laevis metamorphosis. Dev Biol 1997, 182:284-298.

40. Volk H, Charlemagne J, Tournefier A, Ferrone S, Jost R, Parisot R, Kaufman J: Wide tissue distribution of axolotl class II molecules occurs independently of thyroxin. Immunogenetics 1998, 47:339-349.

41. Hermann A, Gowher H, Jeltsch A: Biochemistry and biology of mammalian DNA methyltransferases. Cell Mol Life Sci 2004, 6 I:257I-2587.

42. Fomitcheva J, Baker ME, Anderson E, Lee GY, Aziz N: Characterization of $\mathrm{Ke} 6$, a new $17 \beta$-hydroxysteroid dehydrogenase, and its expression in gonadal tissue. J Biol Chem 1998, 273:22664-2267I.

43. Aziz N, Anderson E, Lee GY, Woo DDL: Arrested testis development in the cpk mouse may be the result of abnormal steroid metabolism. Mol Cell Endocrinol 200I, I7 I:83-88.

44. Putta S, Smith J], Walker JA, Rondet M, Weisrock DW, Monaghan J, Samuels AK, Kump K, King DC, Maness NJ, Habermann B, Tanaka E, Bryant SV, Gardiner DM, Parichy DM, Voss SR: From biomedicine to natural history research: EST resources for ambystomatid salamanders. BMC Genomics 2004, 5:54.

45. Smith JJ, Putta S, Walker JA, Kump DK, Samuels AK, Monaghan JR, Weisrock DW, Staben C, Voss SR: Sal-site: integrating new and existing ambystomatid salamander research and informational resources. BMC Genomics 2005, 6: 181 .

46. Monaghan JR, Walker JA, Page RB, Putta S, Beachy CK, Voss SR: Early gene expression during spinal cord regeneration in the salamander Ambystoma mexicanum. I Neurochem 2007 I 0 I:27-40.

47. Bioconductor: Open Source Software for Bioinformatics [http://www.bioconductor.org]

48. The R Project for Statistical Computing [http://www.rproject.org]

49. Bolstad BM, Irizarry RA, Gautier L, Wu Z: Preprocessing highdensity oligonucleotide arrays. In Bioinformatics and Computational Biology Solutions Using $R$ and Bioconductor Edited by: Gentleman R, Carey VJ, Huber W, Irizarry RA, Dudoit S. New York: Springer; 2005:13-32.

50. Bolstad BM, Collin F, Brettschneider J, Simpson K, Cope L, Irizarry RA, Speed TP: Quality assessment of Affymetrix GeneChip data. In Bioinformatics and Computational Biology Solutions Using $R$ and Bioconductor Edited by: Gentleman R, Carey VJ, Huber W, Irizarry RA, Dudoit S. New York: Springer; 2005:33-47.

51. Irizarry RA, Hobbs B, Collin F, Beazer-Barclay YD, Antonellis KJ, Scherf U, Speed TP: Exploration, normalization, and summaries of high density oligonucleotide array probe level data. Biostatistics 2003, 4:249-264.

52. Sal-Site [http://www.ambystoma.org]

53. Choe SE, Boutros M, Michelson AM, Church GM, Halfon MS: Preferred analysis methods for Affymetrix GeneChips revealed by a wholly defined control dataset. Genome Biol 2005, 6:RI6.

54. Draghici S, Khatri P, Eklund AC, Szallasi Z: Reliability and reproducibility issues in DNA microarray measurements. Trends Genet 2006, 22:101-109.

55. Liu H, Tarima S, Borders AS, Getchell TV, Getchell ML, Stromberg A): Quadratic regression analysis for gene discovery and pattern recognition for non-cyclic short time-course microarray experiments. BMC Bioinformatics 2005, 6: 106 .
56. Benjamini $Y$, Hochberg $Y$ : Controlling the false discovery rate: a practical and powerful approach to multiple testing. J $R$ Stat Soc Ser B 1995, 57:289-300.

57. Smyth GK: Linear models and empirical Bayes methods for assessing differential expression in microarray experiments. Stat Appl Genet Mol Biol 2004, 3:3.

58. Smyth GK: Limma: linear models for microarray data. In Bioinformatics and Computational Biology Solutions Using R and Bioconductor Edited by: Gentleman R, Carey Vj, Huber W, Irizarry RA, Dudoit S. New York: Springer; 2005:397-420.

59. Dennis G, Sherman BT, Hosack DA, Yang J, Gao W, Lane HC, Lempicki RA: DAVID: database for annotation, visualization, and integrated discovery. Genome Biol 2003, 4(5):P3. Epub 2003 Apr 3 .

60. Rozen S, Skaletsky H: Primer3 on the www for general users and for biologist programmers. Methods Mol Biol 2000, I32:365-386.

61. Bustin SA, Nolan T: Pitfalls of quantitative real-time reversetranscription polymerase chain reaction. J Biomol Tech 2004, 15:155-166

62. Pfaffl MW: A new mathematical model for relative quantification in real-time RT-PCR. Nucleic Acids Res 200I, 29:e45.

Publish with Biomed Central and every scientist can read your work free of charge

"BioMed Central will be the most significant development for disseminating the results of biomedical research in our lifetime. "

Sir Paul Nurse, Cancer Research UK

Your research papers will be:

- available free of charge to the entire biomedical community

- peer reviewed and published immediately upon acceptance

- cited in PubMed and archived on PubMed Central

- yours - you keep the copyright
BioMedcentral 